\title{
The knowledge of children on tooth care: a qualitative and quantitative approach
}

Karina Tonini dos Santos Pacheco ${ }^{\mathrm{a}}$, Manoelito Ferreira Silva Junior ${ }^{\mathrm{b}}$, Renato Moreira Arcieri $^{\mathrm{c}}$, Artênio José Isper Garbin ${ }^{c}$, Cléa Adas Saliba Garbin ${ }^{c}$

\begin{abstract}
Objective: To assess the knowledge of children who participated in an Oral Health Educational Program (OHEP) on the subject "tooth care".

Methods: The study was conducted on children aged 6 to 9 years, participating in activities developed twice a week in an OHEP during one academic year. Data were collected by redactions and drawings. Drawings were analyzed according to the methodology proposed by Taylor, Roth and Mayberry. The redactions were analyzed according to the citation of hygiene items and the content presented, taking as theoretical reference the content analysis of Bardin.

Results: All children mentioned the toothbrush and toothpaste as oral hygiene items. As a negative aspect to oral health, candies were mentioned by $74.4 \%$ of children, with greatest citations of confections, chewing gum and lollipop. All redactions mentioned aspects of toothbrushing, such as frequency, technique and/or quality. The consequences of "not caring" were also present, and were related to dental caries, edentulism, halitosis, pain, and personal relationship. The reason for caring was also mentioned, and was related to the importance of teeth for the individual, and "clean", "healthy" and "bright" teeth.
\end{abstract}

Conclusion: The children presented satisfactory understanding on tooth care, evidencing the importance of oral health education programs for this population.

Key words: Health Promotion. Oral Health. Health Education.

\section{O conhecimento das crianças sobre o cuidado com os dentes: uma abordagem quantitativa e qualitativa}

\section{RESUMO}

Objetivo: Avaliar o conhecimento de crianças participantes de um Programa de Promoção em Saúde Bucal (PPSB) sobre o tema "como cuidar dos dentes".

Métodologia: $O$ estudo foi realizado em crianças de 6 a 9 anos de idade, participantes das atividades desenvolvidas duas vezes por semana no PPSB durante um ano letivo. Os dados foram coletados por redações e desenhos. Os desenhos foram analisados de acordo com a metodologia proposta por Taylor, Roth e Mayberry. As redações foram analisadas de acordo com a citação de itens de higienização e pelo conteúdo apresentado, utilizando como referencial teórico a análise de conteúdo de Bardin.

Resultados: Todas as crianças mencionaram a escova de dente e o creme dental como itens de higiene bucal. Como aspecto negativo para a saúde oral, os doces foram mencionados por $74,4 \%$ das crianças, com maiores citações de balas, chicletes e pirulito. Todas as redações mencionaram aspectos da escovação dental, tais como frequência, técnica e/ou qualidade. As consequências da "não cuidar" também estavam presentes, e foram relacionadas à cárie dentária, edentulismo, halitose, dor e relacionamento pessoal. O porquê de cuidar também foi mencionado, e estava relacionado à: importância dos dentes para o indivíduo, dentes "limpinhos", "saudáveis" e "brilhantes".

Conclusão: As crianças apresentaram entendimento satisfatório sobre o cuidado dos dentes, evidenciando a importância de programas de educação em saúde bucal para essa população.

Palavras-chave: Promoção da saúde. Saúde Bucal. Educação em Saúde.

\author{
a Department of Social Medicine at Federal \\ University of Espírito Santo, Brazil \\ ${ }^{\mathrm{b}}$ Department of Social Dentistry, Faculty Dentistry \\ of Piracicaba (FOP/UNICAMP), Brazil \\ ${ }^{c}$ Post-Graduation Program in Preventive and \\ Community Dentistry at Araçatuba School of \\ Dentistry, São Paulo State University (UNESP), \\ Brazil
}




\section{INTRODUCTION}

Dental caries considerably influences the quality of life and welfare of children, especially in its severe manifestation in the deciduous dentition, which may impair the dietary habits, body growth and weight, as well as their social behavior [1-3]. Untreated dental caries is common in children from several countries. In Brazil, its prevalence in childhood remains a public health problem, as evidenced in the last national epidemiological survey, which revealed that $53.4 \%$ of 5-year-old children have caries in the deciduous dentition and dental caries prevalence at 12 years of age was $56.5 \%$ in the permanent dentition [4]. Marra et al. [5] mentioned that, even though Dentistry has presented great technological and scientific advances, the Brazilian population in general presents early tooth loss, and the difficult access to care combined to lack of information make people believe that this is unavoidable. Currently, the prevention of oral diseases and oral health maintenance are the main challenges in Dentistry [6]. For that purpose, oral health education plays an essential role.

The school is understood as an obvious environment for teaching, thus being appropriate for oral health prevention practices [7]. This method is efficient and effective, due to the easy organization, low cost $[8,9]$ and short-term outcomes [9]. Also, by reaching the children, it indirectly reaches their families and communities [10]. The results of oral health education at school presents positive outcomes, both in developing $[9,11]$ and developed countries $[8,9,12]$.

The school-based oral health educational programs are effective in improving the knowledge, attitude and practice regarding oral health, as demonstrated in the systematic review of Nakre and Harikiran [13] and in the research of Conrado, Oliveira and Maciel [14]. For the program to be effective, aspects must be observed, such as the timing of educational activities of the program [15] and the involvement of parents and teachers in the process $[13,15]$.

The level of knowledge on oral health by the society is extremely important for planning and evaluation of oral health actions and search for strategies based on collected data, which was the aim of this study.

To assess knowledge of children on aspects related to oral health is a very important way for clinical practice, establishment and evaluation of educational programs for this population. Thus, this article aimed to assess the knowledge of children who participated in an Oral Health Educational Program (OHEP) on the subject "tooth care".

\section{METHODS}

\section{Study design and sample}

This exploratory descriptive study had a quantitative and qualitative approach. Sample selection was based on the need to assess the knowledge of a group of children who participated in an Oral Health Educational Program (OHEP).
The study was conducted on 60 children aged 6 to 9 years, participating in activities developed twice a week in an OHEP during one academic year. These children attended the school at one period and a project called "Our child" in the opposite period, held at a non-profit organization at the city of Araçatuba-SP, Brazil. The aim of this project is to take children away from social risk situation and offer them productive activities while their parents work. The OHEP is included among the activities of this project and includes educational and preventive oral health actions. The actions were developed by dental students and teachers.

The subjects more frequently addressed in the educational process are: importance of oral and systemic health; dental plaque - what it is, how it forms and consequences, how to remove it; hygiene habits - toothbrushing, use of dental floss; dietary habits - diet/caries relationship; fluoride and harmful habits (non-nutritive sucking habits - pacifiers and finger). Education sessions lasted about 20 minutes and comprised didactic role plays, drawings and paintings, music, audiovisual media (slide projector, dental model form, charts, photo albums, posters) and playing educational activities (figures docking, dominoes, puzzle, memory games, hopscotch)

Supervised toothbrushing is performed weekly, and children requiring individual care are referred to a dental office available in the project, in partnership with Araçatuba School of Dentistry, São Paulo State University, São Paulo, Brazil.

\section{Methods}

Data were collected after one academic year of project development. The knowledge on the subject "tooth care" were collected by redactions, allowing free writing on the subject. To allow the participation of all children attending the project, drawings were used as an option for those who were not alphabetized. According to Marshman and Hall [16], drawings may be used in several manners to investigate children and their relationship with Dentistry.

To assure the child was feeling comfortable, the investigator was not present during the activities, which were included in their daily routine of activities in the project. However, Marshman and Hall [16] mentioned that, in schools, the responses of children may be influenced by colleagues and teachers, thus the caretakers (who care for these children daily) were asked not to talk with the children during the activities, as well as not to allow them the children to communicate with each other. To start the preparation of materials, the caretakers asked the children to draw a picture or write about how to care for the teeth. Data were collected by two caretakers (class in the morning and afternoon) and the children had two hours to prepare the material.

The drawings were analyzed by the method proposed by Taylor, Roth and Mayberry [17], based on the occurrence (frequency) of some items, namely hygiene items in this study (Figure 1). When the child completed the work, he or she was asked to confirm the contents with the aid of a 
pedagogue. This moment, the negative or positive values for the items were assigned.

The redactions were analyzed according to the citation of oral hygiene items and the content presented. Thus, the content was analyzed by the categories analysis technique proposed by Bardin [18]. This technique has three steps: preanalysis, material exploration, processing and interpretation of results obtained by the theoretical framework. The main subject was initially identified, followed by the categories within it. Categories emerged according to the answers given by the research participants. Sentences with the same meaning were grouped in a same category, even if they were written differently.

\section{Ethical aspects}

The study was approved by the Institutional Review Board of Araçatuba School of Dentistry, São Paulo State University, Brazil (process FOA 2007-01843). All parents of children signed an informed consent form. The study followed the ethical principles of Brazilian Regulation 196/96 [19], which foresees the guidelines and regulations for studies in human beings.

\section{RESULTS}

The final sample was composed of 43 children aged 6 to 9 years attending the institution at the day when the study was conducted, being $25(58.1 \%)$ girls and $18(41.9 \%)$ boys. Among the children, 12 expressed by drawings and 31 made redactions.

Concerning the occurrence of oral hygiene items in drawings and redactions, $100 \%$ of children mentioned the toothpaste and toothbrush, $67.4 \%$ dental floss, $18.6 \%$ fluoride and $65.1 \%$ mouthrinse.

With regard to diet, $74.4 \%$ of children mentioned candies as a negative aspect for oral health, with predominance of citation and drawing of confections, chewing gums and lollipops.

The following representations were included in the drawings: body hygiene associated with oral hygiene; association between decayed teeth and extraction; representation of "happy" or "clean" tooth associated with hygiene elements, representation of toothbrushing (Figure 1 and 2).

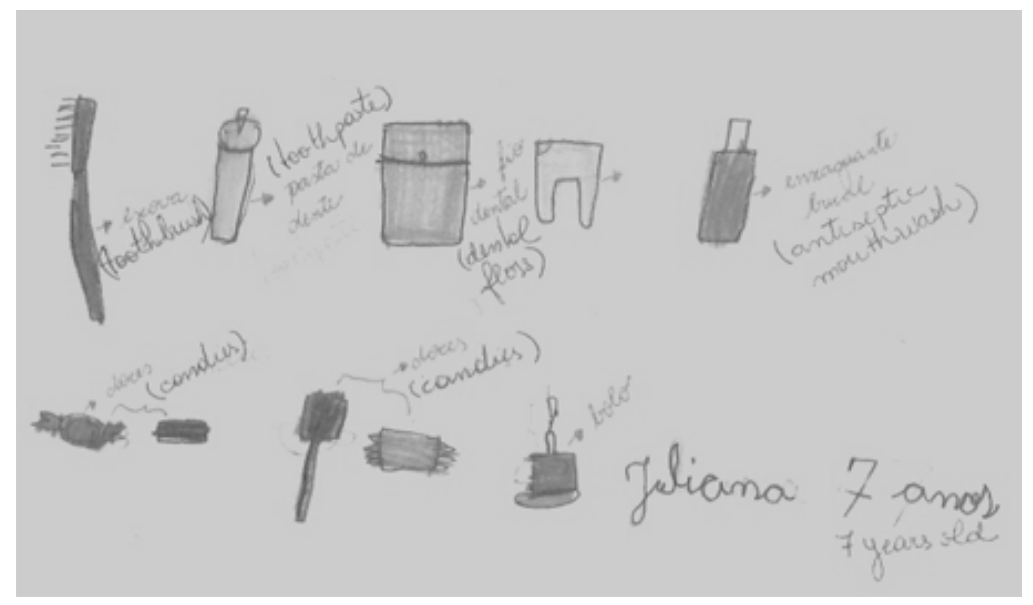

Fig.1. Drawing made by a seven-year-old child, containing several elements of oral hygiene.

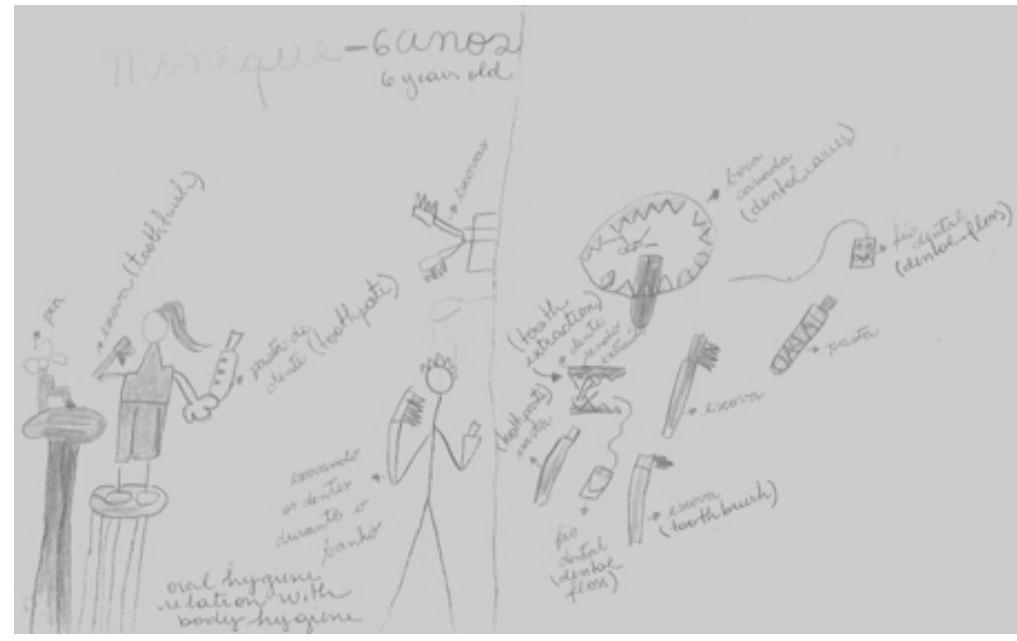

Fig. 2. Drawing made by a six-year-old child, representing body hygiene associated ro oral hygiene and the association between decayed teeth and extraction. 
In the redactions, the central subjects were: aspects of toothbrushing (frequency, technique and/or quality) (Table 1), consequences of lack of care for the mouth (Table 2) and why to care for the mouth (Table 3).

Table 1. Categories related to the subject "toothbrushing" mentioned by children in their redactions. Araçatuba, São Paulo, Brazil, 2009.

\begin{tabular}{|c|c|}
\hline \multicolumn{2}{|r|}{ Subject: Toothbrushing } \\
\hline Categories & Perceptions \\
\hline Frequency & $\begin{array}{l}\text { "I brush my teeth three times a day." } \\
\text { "Never forget to brush the teeth." }\end{array}$ \\
\hline Technique & $\begin{array}{l}\text { "It is important not to forget tongue brushing." } \\
\text { "Brush the teeth with small quantity of toothpaste." } \\
\text { "I will explain how to brush: circles in front and } \\
\text { lateral sides of teeth, back and forth in back sides } \\
\text { and up and down in inner sides, and not forgetting } \\
\text { to brush the tongue. The toothbrush must also be } \\
\text { changed, ok?" }\end{array}$ \\
\hline Quality & $\begin{array}{l}\text { "Brushing all teeth and very well." } \\
\text { "It is so good to have our friend 'toothbrushy'." }\end{array}$ \\
\hline $\begin{array}{l}\text { Technique and } \\
\text { quality }\end{array}$ & $\begin{array}{l}\text { "I must brush the teeth very well, otherwise there } \\
\text { will be many bacteria. How to brush: making circles } \\
\text { and back and forth movements." }\end{array}$ \\
\hline $\begin{array}{l}\text { Frequency and } \\
\text { quality }\end{array}$ & "Brush the teeth very well and every day." \\
\hline $\begin{array}{l}\text { Frequency and } \\
\text { technique }\end{array}$ & $\begin{array}{l}\text { "Brush the teeth in the morning, at lunch time and } \\
\text { night... Brush the tongue, all sides of teeth must } \\
\text { be brushed." }\end{array}$ \\
\hline
\end{tabular}

Table 2. Categories related to the subject "consequences of not caring for the mouth" mentioned by children in their redactions. Araçatuba, São Paulo, Brazil, 2009

\begin{tabular}{|c|c|}
\hline \multicolumn{2}{|c|}{ Subject: consequences of not caring for the mouth } \\
\hline Categories & Perceptions \\
\hline $\begin{array}{l}\text { Caries and } \\
\text { edentulism }\end{array}$ & $\begin{array}{l}\text { "If we don't brush the teeth we become } \\
\text { 'toothless'." } \\
\text { "If we take good care, we don't need to pull the } \\
\text { teeth out." }\end{array}$ \\
\hline Halitosis & $\begin{array}{l}\text { "The mouth will be stinking, rotten, full of caries, the } \\
\text { mouth becomes ugly and very stinky." }\end{array}$ \\
\hline $\begin{array}{l}\text { Personal } \\
\text { relationship }\end{array}$ & $\begin{array}{l}\text { "... because otherwise they become rotten and no } \\
\text { one would like to talk to me." } \\
\text { "... when you grow up, that caries will always be on } \\
\text { your tooth and, if you are a boy, the girl will never } \\
\text { want to date you..." }\end{array}$ \\
\hline
\end{tabular}

Table 3. Categories related to the subject "why to care for the mouth" mentioned by children in their redactions. Araçatuba - SP, Brazil, 2009.

\begin{tabular}{|c|c|}
\hline \multicolumn{2}{|r|}{ Subject: why to care for the mouth } \\
\hline Categories & Perceptions \\
\hline Healthy teeth & $\begin{array}{l}\text { "Taking care of teeth every day to be beautiful, } \\
\text { clean and healthy." } \\
\text { "Let's make our teeth beautiful, white and very } \\
\text { healthy." }\end{array}$ \\
\hline $\begin{array}{l}\text { Importance of } \\
\text { teeth for the } \\
\text { individual }\end{array}$ & $\begin{array}{l}\text { "Caring for the teeth is very good for our health." } \\
\text { "The teeth are important for the people." }\end{array}$ \\
\hline $\begin{array}{l}\text { Wish to be a } \\
\text { dentist }\end{array}$ & $\begin{array}{l}\text { "Since I will be a dentist, I must know how to care } \\
\text { for my mouth..." }\end{array}$ \\
\hline
\end{tabular}

\section{DISCUSSION}

Currently, greater emphasis is given to what the child thinks and feels, in the so-called child-centered research [16], thus this study was conducted on the children themselves. Studies on children often address the perception of their parents instead of their own, which may impair the outcome and post-research approaches.

In general, in the present study, the perception of children on tooth care may be considered satisfactory, considering the high frequency of citations of important elements for oral hygiene. These findings agree with Antunes et al. [20] concerning the perception of children aged 6-7 years on oral hygiene, in which $100 \%$ selected toothbrushing and toothpaste and $96.7 \%$ indicated dental floss in a multiple choice questionnaire.

Conversely, Liu et al. [21] conducted a study with a self-applied questionnaire and observed that only $64 \%$ of Chinese children confirmed the preventive effect of toothpaste. The authors concluded that there is the need of oral health programs at the schools to promote the use of fluoridated dentifrice among schoolchildren.

The frequency of citation of mouthrinse by the children was remarkable, and was probably influenced by the media or even by the parents, since this product is not mentioned in the educational work conducted in the present OHEP.

Most children mentioned candies as a negative aspect to oral health, in disagreement with Antunes et al. [20] who revealed contradictory responses concerning the intake of sugar, since the children related them as beneficial to the teeth, indicating candies and chocolates as "tooth friendly". This fact was also observed in the study of Freire, Soares and Pereira [22], in which only $36.7 \%$ of children in the sample (aged 6-13 years) mentioned correct options, indicating the candies as "tooth unfriendly".

Also, the drawings revealed standpoints on the aspect of oral hygiene inserted in the daily hygiene of the child, and the association of "happy tooth" besides oral hygiene items. It should be mentioned that the OHEP strongly addresses the representation of "happy tooth" and "sad tooth", i.e. some children represent this idea similarly to the project.

Another important aspect that restates the reproduction of educational activities of the OHEP is that all redactions mentioned aspects of toothbrushing, such as its frequency, technique and/or quality, some mention the way the technique is addressed (back and forth, circles) and characters of stories told to them (the 'Toothbrushy').

The consequences of "not caring" were mentioned in the redactions and were related with caries, edentulism, halitosis, personal relationship, i.e. the children notice that the esthetic dimension is inherent to the anatomical region where the teeth are. The "why to care for the mouth" was also mentioned, and was related to "clean", "healthy" and "bright" teeth, as well as the importance of teeth for the individual, in agreement with the studies of Al-Omiri, Al-Wahadni and Saeed [23], whose children included as 
subjects also acknowledged the importance of oral health for the welfare of individuals.

It should be mentioned that data collection by redaction was selected due to the freedom allowed by this method, since the child may express the ideas on the paper, without restrictions. No studies were found in the literature including the utilization of free writing in studies on children, and most studies comprise interviews or self-applied questionnaires [20-23]. In case of interview, the child may be inhibited by the presence of the investigator, and in case of forms or multiple-choice questions the child may be influenced.

The results of this study, considering the subjects addressed in the OHEP, suggest that it may contribute to a more adequate knowledge of children on tooth care. However, Santos, Nadanovsky and Oliveira [24] alert about the ethical duty of health professionals of assure that knowledge diffused in oral health education to the target population is based on scientific support.

According to Miller et al. [25], oral health programs may actually act as a small step for children to reach autonomy in oral hygiene practices. This evidences the importance of oral health education programs for schoolchildren for making healthier decisions and the ability to positively influence the community where they live.

Pauleto et al. [26] emphasize that, despite the existence of several programs, the educational dimension is undeveloped and, when performed, is strongly supported by practices of transmitting knowledge, without space for dialogic practices capable of mobilizing children about issues of oral health, which aims at achieving autonomy in relation to health care. Thus, Meyer et al. point to the need of educational practices taking into account the vulnerability of people, seeking to know the reality of the subject contextualizing the risks and causes of diseases. Guimarães and Lima [27] add that health education involves educating for life and, therefore, the students should be prepared to develop the ability of analysis, discernment and decision.

According to Chapman, Copestake and Duncan [8], even though this may be a complicated process, schoolchildren receive information that may be part of the first step toward the establishment of their beliefs and attitudes, which may lead them to healthier choices in the long term.

\section{CONCLUSION}

The children presented adequate knowledge on tooth care, evidencing the importance of oral health education programs for this population.

\section{REFERENCES}

1. Low W, Tan S, Schwartz S. The effect of severe caries on the quality of life in young children. Pediatr Dent. 1999;21(6):325-6.

2. Sheiham A. Dental caries affects body weight, growth and quality of life in pre-school children. Br Dent J. 2006;201(10):625-6. https://doi. org/10.1038/sj.bdj.4814259

3. Wandera M, Kayondo J, Engebretsen IM, Okullo I, Astrom AN. Factors associated with caregivers' perception of children's health and oral health status: a study of 6- to 36-month-olds in Uganda. Int J Paediatr Dent. 2009; 19(4):251-62. https://doi.org/10.1111/j.1365-263X.2009.00969.x
4. Brasil. Ministério da Saúde. Secretaria de Atenção à Saúde. Projeto SB Brasil 2010: resultados principais [internet]. [cited 2013 jan 15]. Available from: http://dab.saude.gov.br/cnsb/sbbrasil/index.html.

5. Marra SP, Lagreca PD, Martins VR, Oliveira AV, Vils AB, Chevitarese L, Miasato JM. Atraumatic restorative treatment: an alternative of life quality recuperation. Rev Odontol Univ Cid São Paulo. 2008;20(2):204-8.

6. Balaban R, Aguiar CM, Araújo ACS, Dias-Filho EB. Knowledge of paediatricians regarding child oral health. Int J Paediatr Dent. 2012:22(4): 286-91. https://doi.org/10.1111/j.1365-263X.2011.01196.x

7. Pine CM. Designing school programmes to be effective vehicles for changing oral hygiene behaviour. Int Dent J. 2007:57 (Suppl. 5):377-81. https://doi.org/10.1111/j.1875-595X.2007.tb00164.x

8. Chapman A, Copestake SJ, Duncan K. An oral health education programme based on the National Curriculum. Int J Paediatr Dent. 2006; 16 (Suppl. 5):40-4. https://doi.org/10.1111/j.1365-263X.2006.00677.x

9. Yazdani R, Vehkalahti MM, Nouri M, Murtomaa H. School-based education to improve oral cleanliness and gingival health in adolescents in Tehran Iran. Int J Paediatr Dent. 2009;19(4):274-81. https://doi.org/10.1111/j. 1365-263X.2009.00972.x

10. Oral Health Promotion through Schools. Geneva: World Health Organization; 2003. WHO Information Series on School Health. Document 8.

11. Petersen PE, Peng B, Tai B, Bian Z, Fan M. Effect of a school-based oral health education program in Wuhan city, People's Republic of China. Int Dent J. 2004;54(1):33-41. https://doi.org/10.1111/j.1875-595X.2004 tb00250.x

12. Biesbrock AR, Walters PA, Bartizek RD. Initial impact of a national dental education program on the oral health and dental knowledge of children. J Contemp Dent Pract. 2003:4(2):1-10.

13. Nakre PD, Harikiran AG. Effectiveness of oral health education programs A systematic review. J Int Soc Prev Community Dent. 2013;3(2):103-15. https://doi.org/10.4103/2231-0762.127810

14. Conrado CA, Maciel SM, Oliveira MR. A school-based oral health educational program: the experience of Maringa- PR, Brazil. J Appl Oral Sci.2004;12(1):27-33. https://doi.org/10.1590/S1678-77572004000100006

15. Shenoy RP. Sequeira PS. Effectiveness of a school dental education program in improving oral health knowledge and oral hygiene practices and status of 12- to 13-year-old school children. Indian J Dent Res. 2010;21(2):253-9. https://doi.org/10.4103/0970-9290.66652

16. Marshman Z, Hall MJ. Oral health research with children. Int J Paediatr Dent. 2008;18(4):235-242. https://doi.org/10.1111/j.1365-263X.2008.00922.x

17. Taylor D, Roth G, Mayberry W. Children's drawings about dentistry. Community Dent Oral Epidemiol. 1976;4(1):1-6. https://doi.org/ 10.1111/j 1600-0528.1976.tb00960.x

18. Bardin L. Content analysis. 3rd. Lisboa: Edições 70; 2004. 221 p.

19. Conselho Nacional de Saúde (Brasil). Resolução n. 196, de 10 de outubro de 1996. Diretrizes e normas regulamentadoras de pesquisa envolvendo seres humanos [Internet]. Brasília, 2008. [cited 2012 Jun 13]. Available from: http://www.conselho.saude.gov.br/web comissoes/conep/index.html

20. Antunes LS, Soraggi MBS, Antunes LAA, Corvino MPF. Evaluation of the perception of the children and knowledge of the educators on bucca health, diet and hygiene. Pesqui Bras Odontopediatria Clin Integr. 2006;6(1):79-85

21. Liu M, Zhu L, Zhang B, Petersen PE. Changing use and knowledge of fluoride toothpaste by schoolchildren, parents and schoolteachers in Beijing. China. Int Dent J. 2007;57(3):187-94. https://doi.org/10.1111/א. 1875-595X.2007.tb00124.x

22. Freire MCM, Soares FF, Pereira MF. Knowledge on dental health, diet and oral hygiene of children treated at the Dental School of the Federa University of Goias. J Bras Odontopediatr Odontol Bebe. 2002;5(25):195-9.

23. Al-Omiri MK, Al-Wahadni AM, Saeed KN. Oral health attitudes, knowledge, and behavior among school children in North Jordan. J Dent Educ. 2006; 70(2):179-87.

24. Santos APP, Nadanovsky P, Oliveira BH. Inconsistencies in recommendations on oral hygiene practices for children by professiona dental and paediatric organisations in ten countries. Int J Paediatr Dent. 2011; 21(3): 223-31. https://doi.org/10.1111/j.1365-263X.2011.01115.x

25. Miller FY, Lautar CJ, Meyer JM, Summers DG. Achieving autonomy in dental hygiene practice through a school-based oral health program. J Den Hyg. 2006;80(1):28-8

26. Pauleto ARC, Pereira MLT, Cyrino EG. Oral health: a critical review about educative programmes for students. Ciênc Saúde Coletiva. 2004;9(1): 121-30. https://doi.org/10.1590/S1413-81232004000100012

27. Guimaraes JS \& Lima IMSO. Educação para a Saúde: discutindo uma prática pedagógica integral com jovens em situação de risco. Saude Soc. 2012: 21(4): 895-908. https://doi.org/10.1590/S0104-12902012000400009 